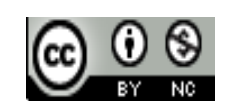

Jurnal Pendidikan Matematika Indonesia is licensed under

A Creative Commons Attribution-Non Commercial 4.0 International License.

\title{
PENINGKATAN PEMAHAMAN KONSEP MATEMATIS SISWA MELALUI PENDEKATAN SAVI (SOMATIC, AUDITORY, VISUAL AND INTELLECTUAL)
}

\author{
Khoerul Umam ${ }^{1)}$, Ervin Azhar ${ }^{2)}$ \\ 1,2) Universitas Muhammadiyah Prof. DR. HAMKA, Jakarta, Indonesia \\ E-mail: khoerul.umam@uhamka.ac.id
}

\begin{abstract}
Abstrak. Pengembangan pemahaman konsep matematika yang baik akan meningkatkan kemampuan pemecahan masalah matematika siswa. Pendekatan SAVI menawarkan suatu konsep pembelajaran matematika yang integratif dengan mengintegrasikan banyak aspek. Penelitian ini dirancang dengan desain kuasi eksperimen. Subjek penelitian pada kelas eksperimen berjumlah 36 siswa sedangkan kelas kontrol terdiri dari 35 siswa. Analisis data menggunakan statistic deskriptif. Berdasarkan hasil studi menunjukkan siswa yang diberikan pembelajaran dengan pendekatan SAVI mengalami peningkatan pemahman konsep matematis secara siginifikan. Pemahaman konsep siswa yang diajarkan oleh pendekan SAVI memiliki kelebihan dalam menganalisis masalah melalui konstruksi konsep matematika.
\end{abstract}

Keyword: SAVI, Pemahman Konsep Matematis.

\section{PENDAHULUAN}

Pembelajaran matematika tidak harus selalu berorentasi pada hasil belajar siswa (Ero-Tolliver, Lucas, \& Schauble, 2013; Suswandari, Armiyati, Umam, Asiah, \& Susanti, 2017; Umam, 2011; Umam, Nusantara, Parta, Hidayanto, \& Mulyono, 2019). Pembelajaran matematika sebaiknya mengedepankan konstruksi konsep matematis. Pembelajaran yang berorentasi pada konstruksi konsep akan memberikan nilai tambah bagi perkembangan kognitif siswa. Anhalt \& Cortez, (2016) menjelaskan bahwa pembelajaran yang berorentasi pada konstruksi konsep akan berusaha melibatkan peranan siswa dalam mengaitkan konsep-konsep matematika. Kemampuan siswa untuk mengaitktan antar konsep-konsep matematika membutuhkan kemampuan pemahaman konsep matematis yang baik. Hal ini akan memberikan dasar bagi perkembangan pembelajaran matematika siswa(Borchardt \& Bozer, 2017; Septiany, Purwanto, \& Umam, 2015; Tague \& Czocher, 2016; Umam, Nusantara, Parta, \& Hidayanto, 2018).
Studi pendahuluan awal yang telah dilakukan pada kelas VIII telah menunjukkan bahwa 10 siswa memiliki kemampuan pemahaman konsep matematika yang tinggi, 25 siswa memiliki kemampuan pemahaman konsep matematis yang sedang, dan 36 siswa memiliki kemampuan pembahaman konsep yang rendah. Hal ini tentunya menjadi sesuatu yang perlu diperhatikan mengingat pemahaman konsep berperan penting dalam pembelajaran matematika.

Berdasarkan hasil ujian tengah Semester Ganjil, kelas VIII di SMP tahun pelajaran 2017/2018 diperoleh nilai rata-rata matematika adalah 4,63 dari skala 10 . Oleh karena itu dari data survei menunjukan rendahnya skor rata-rata prestasi matematika siswa, hal ini terjadi karena kurangnya kemampuan pemahaman siswa dalam memahami konsep. Rendahnya kemampuan pemahaman siswa bisa terjadi pada sekolah lain, yang sebagian besar peserta didik menganggap matematika merupakan salah satu pelajaran yang dianggap sulit, hal ini karena matematika berhubungan dengan ide-ide atau konsep yang abstrak sehingga dapat mengakibatkan siswa menjadi pesimis dan kurang termotivasi dalam mempelajarinya dan tentunya akan berpengaruh terhadap 


\section{A- - - Jurnal Pendidikan Matematika Indonesia \\ Volum 4 Nomor 2 bulan September 2019 Page 53 - 57 \\ p-ISSN: 2477-5967 e-ISSN: 2477-8443}

pemahaman yang mereka capai dalam belajar(Umam \& Supiat, 2019; Umam \& Yudi, 2016). Hal tersebut merupakan faktor yang melatarbelakangi rendahnya kemampuan pemahaman siswa.

Faktor lainnya yang mungkin terjadi adalah situasi proses pembelajaran dikelas yang kurang membangkitkan keaktifan siswa, minimnya keterlibatan siswa dalam proses pembelajaran, selain itu siswa hanya di posisikan sebagai penerima informasi dari guru. Hal ini mengakibatkan siswa mengalami kesulitan dalam memahami konsep saat pembelajaran matematika(Alim, Umam, \& Rohim, 2015; Alim, Umam, \& Wijirahayu, 2016; Umam, 2018). Menyikapi hal tersebut perlu adanya evaluasi dalam proses pembelajaran, yaitu dengan cara merefleksikan kembali penyajian proses belajar yang dilakukan oleh guru, yang pada umumnya menggunakan pendekatan pembelajaran konvensional.

Pembelajaran yang kreatif, inovatif, dan berbobot dikemukakan oleh para pakar dalam bidang pendidikan untuk mengatasi permasalahan yang ada. Pembelajaran matematika dengan pendekatan (Somatic, Auditory, Visual and Intellectual) dapat meningkatkan kemampuan pemahaman konsep matematis siswa. Hal ini disebabkan pendekatan pembelajaran yang meggabungkan gerakan fisik dengan aktivitas intelektual serta penggunaan semua alat indera.

Rizky, Ariyanto, \& Sutrisno, (2017) menyatakan bahwa pembelajaran yang menggunakan gerakan dapat memberikan pengalaman belajar kepada siswa sehingga proses pembelajaran menjadi lebih bermakna, selain itu pembelajaran dengan melibatkan indera pendengaran dapat membantu siswa untuk merekam dan mencerna informasi yang diperoleh, keterlibatan indra penglihatan pun tak kalah pentingnya karena dengan penglihatan dapat memvisualisasikan ide-ide yang terkait dalam kehidupan nyata, dan yang paling utama manusia dibekali dengan kemampuan berfikir yang harus diberdayakan dengan pendidikan sehingga siswa dapat berlatih berfikir kritis, bernalar untuk menyelidiki, mengidentifikasi, menemukan, mencipta, mengkontruksi, memecahkan masalah dan menerapkannya dalam kehidupan sehari-hari. Pembelajaran dengan menggunakan pendekatan SAVI yaitu menggabungkan keempat unsur SAVI ke dalam satu peristiwa pembelajaran (Husita, 2014; Nio, 2016; Sutarna, 2018). Empat unsur SAVI diantaranya somatic, auditory, visual and intellectual.

\section{a. Somatic}

Pembelajaran matematika akan berlangsung dengan baik jika diawali dengan kegiatan yang mampu meningkatkan daya kerja otak dan konsentrasi siswa dalam memulai pembelajaran. Pemebelajaran ini mengarahkan agar guru dapat memberi bantuan baik media ataupun cerita yang dapat meningkatkan keinginan siswa untuk belajar matematika.

a. b.Auditory

Dalam pembelajaran matematika untuk menarik saluran auditory, guru dapat mengajak siswa membicarakan materi bangun ruang yang sedang dipelajari. Salah satu contoh prakteknya dalam pembelajaran yaitu guru mendorong siswa untuk menyebutkan benda-benda di sekitar kelas yang memiliki bentuk balok, kubus dan bangun ruang lainnya. Setelah siswa berhasil menunjukkan benda-benda tersebut, siswa diminta untuk menyebutkan unsur-unsur yang terdapat dalam bangun ruang yang telah diungkapkan sebelumnya (Canellas \& Kendall, 2018; Husita, 2014).

b. c. Visual

Dalam pembelajaran matematika untuk menarik kemampuan visual, guru dapat meminta siswa untuk menjelaskan kembali materi tentang bangun ruang yang telah dibahas dengan menggunakan menggunakan bahan ajar visual. Hal ini dapat memberikan kesempatan kepada siswa lainya untuk dapat melihat secara langsung bentuk alat peraga yang dipakai sehingga hal ini memungkin siswa untuk lebih memahami konsep matematis (EroTolliver et al., 2013).

\section{c. d. Intelektual}

Kemampuan intelektual siswa ditingkatkan dengan memberikan masalah pemodelan matematika yang mengajak siswa tidak hanya menyelesaikan masalah tetapi juga mendorong siswa untuk mensimulasikan kejadian yang sesungguhnya (Sutarna, 2018). Contoh: Sebuah lapangan bola basket akan dicat ulang dengan tiga lapisan. Lapisan pertama memiliki lebar 16 meter dan panjang 24 meter sedang lapisan kedua memiliki panjang 14 meter dan panjang 22 meter. Hitunglah berapa lama waktu yang dibutuhkan jika pengecatan setiap meter persegi membutuhkan waktu 20 menit?.

Pendekatan SAVI dalam pembelajaran tidak harus selalu berurutan dari somatic, auditory, visual kemudian intellectual, akan tetapi bisa di mulai dari yang mana saja, baik dimulai dari auditory, visual, intellectual kemudian somatic ataupun urutan lainnya(Nio, 2016). Hal yang perlu diperhatikan dalam pembelajaran dengan menggunakan pendekatan SAVI bahwa ke empat unsur tersebut harus berada pada satu peristiwa pembelajaran. Dengan demikian aktivitas tersebut akan menarik perhatian siswa sehingga siswa merasa senang dalam pembelajaran matematika dan pembelajaran matematika menjadi tidak membosankan.

\section{II.METODE PENELITIAN}

Penelitian menggunakan desain kuasi eksperimen. Desain ini memungkinkan peneliti untuk tidak mengubah situasi pembelajaran yang telah berlangsung di sekolah. Penelitian ini menggunakan dua kelas yang memiliki 


\section{- - - Jurnal Pendidikan Matematika Indonesia \\ Volum 4 Nomor 2 bulan September 2019 Page 53 - 57 \\ p-ISSN: 2477-5967 e-ISSN: 2477-8443}

karakteristik yang sama. Pembelajaran yang dilakukan pada kelas eksperimen menggunakan pembelajaran dengan pendekatan SAVI, sedangkan pembelajaran pada kelas kontrol menggunakan pembelajaran matematika konvensional.

Demografi subjek penelitian pada kelas VIII yang sekitar 71 siswa SMP terdiri dari 36 siswa di kelas eksperimen dan 35 siswa kelas kontrol. Pengukuran pemahaman konsep matematis siswa akan disusun dalam bentuk esai dengan tujuan mengetahui tahapan prosedur yang siswa kerjakan pada saat menyelesaikan masalah matematika. Instrumen pemahaman konsep yang dikembangkan dengan mengacu pada masalah pemodelan matematika. Analisis data menggunakan analisis statistik deskriptif, dan pengujian hipotesis sehingga dapat mempresentasikan hasil pemahaman konsep matematis siswa secara lebih komprehensif.

\section{III.HASIL DAN PEMBAHASAN}

\section{Pengujian Hipotesis}

Hasil pengujian persyaratan analisis data terhadap kedua kelas telah menunjukkan berdistribusi normal dan berasal dari varians yang homogen, sehingga dapat dilanjutkan dengan uji hipotesis penelitian. Dari data penelitian berdasarkan skor data kemampuan pemahaman konsep matematis siswa pada kelas eksperimen dan kelas kontrol diperoleh skor rata-rata dan simpangan baku yang disajikan pada tabel 1 berikut :

TABEL 1

DATA KELAS EKSPERIMEN DAN KELAS KONTROL

\begin{tabular}{lccc}
\hline \multicolumn{1}{c}{ Kelas } & Jumlah Siswa & Mean & $\begin{array}{c}\text { Simpangan } \\
\text { Baku }\end{array}$ \\
\hline Eksperimen & 36 & 22,527 & 5,598 \\
Kontrol & 35 & 20,057 & 6,154 \\
\hline
\end{tabular}

Berdasarkan data tabel 1 menunjukkan bahwa ratarata hasil yang diperoleh oleh siswa yang diajarkan dengan pendekatan SAVI lebih tinggi dibandingkan dengan rata-rata skor pada siswa kelas kontrol. Pencapain hasil yang berbeda ini tidak menunjukkan bahwa pembelajaran dengan menggunakan pendekata SAVI terbukti efektif untuk meningkatkan pemahaman konsep siswa. Pembelajaran yang mendorong siswa untuk aktif dalam proses belajar cenderung dapat meningkatkan pemahaman konsep siswa (Long, Cummins, \& Waugh, 2017). Hasil ini akan digunakan untuk melakukan uji hipotesis penelitian dengan menggunakan uji-t. Hasil uji-t menunjukkan bahwa :

TABEL 2

HASIL UJI-T

\begin{tabular}{ccc}
\hline $\boldsymbol{t}_{\text {hitung }}$ & $\boldsymbol{t}_{\text {tabel }}$ & Kesimpulan \\
\hline 1,770 & 1,669 & Tolak Ho
\end{tabular}

Dari data yang diperoleh pada tabel diatas nilai $t_{\text {hitung }}>t_{\text {tabel }}$, hal ini menyebabkan $\mathrm{H}_{0}$ ditolak dan $\mathrm{H}_{1}$ diterima, artinya bahwa terdapat pengaruh penggunaan pendekatan SAVI terhadap kemampuan pemahaman

konsep matematis siswa. Hasil menunjukkan siswa yang belajar dengan menggunakan pendekatan SAVI memiliki kemampuan pemahaman matematis yang lebih baik. Kemampuan itu ditunjukkan dengan kemampuan siswa menganalisis masalah matematika melalui konstruksi konsep matematika. Namun, siswa pada kelas kontrol masih mengalami kesulitan dalam pemahaman konsep sehingga diperlukan suatu pembelajaran dengan waktu ekstra.

\section{Kemampuan Pemahaman Konsep Matematis Siswa}

Berdasarkan data yang diperoleh dari analisis data hasil penelitian telah menunjukkan bahwa $H_{0}$ dengan taraf signifikansi $\alpha=0,05$ ditolak. Hasil perhitungan ini menunjukkan bahwa pembelajaran matematika dengan pendekatan SAVI dapat mempengaruhi kemampuan pemahaman konsep matematis siswa di SMP Bekasi.

TABEL 3

KEMAMPUAN PEMAHAMAN KONSEP MATEMATIS SISWA

\begin{tabular}{lcccc}
\hline \multicolumn{1}{c}{ Kelas } & $\begin{array}{c}\text { Skor } \\
\text { Ideal }\end{array}$ & $\begin{array}{c}\text { Rata-Rata } \\
\text { Skor }\end{array}$ & $\begin{array}{c}\text { Rata-Rata } \\
\text { Nilai }\end{array}$ & Persentase \\
\hline Eksperimen & \multirow{2}{*}{40} & 22,527 & 56,319 & $56,32 \%$ \\
Kontrol & 20,057 & 50,142 & $40,142 \%$ \\
\hline
\end{tabular}

Berdasarkan tabel 3 terlihat hasil rata-rata tes kemampuan pemahaman konsep matematis siswa yang diperoleh siswa ekperimen meningkat secara signifikan. Rata-rata kemampuan pemahaman konsep matematis siswa yang belajar dengan menggunakan pendekatan SAVI lebih tinggi dibandingkan dengan pembelajaran dengan cara yang lainnya. Dari hasil yang didapat skor ideal sebesar 40 dengan kelas eksperimen mencapai 22,527 atau sebesar 56,32\% dari skor ideal, sedangkan kelas kontrol mencapai skor 20,057 atau sebesar 40,142\% dari skor ideal. Dalam penelitian ini selain mengukur rata-rata keseluruhan namun juga mengukur tingkat presentase setiap indikator kelas eksperimen akan dijelaskan lebih lanjut pada tabel 4 sebagai berikut;

TABEL 4

INDIKATOR KEMAMPUAN PEMAHAMAN KONSEP MATEMATIS SISWA KELAS EKSPERIMEN

\begin{tabular}{|c|c|c|c|}
\hline \multirow[t]{2}{*}{ No } & \multirow{2}{*}{$\begin{array}{l}\text { Indikator Kemampuan } \\
\text { Pemahaman Konsep }\end{array}$} & \multicolumn{2}{|c|}{ Kelas Eksperimen } \\
\hline & & Pre-test & Post-test \\
\hline 1 & $\begin{array}{l}\text { Memberikan contoh konsep } \\
\text { bangun ruang dari lingkungan } \\
\text { sekitar }\end{array}$ & $56,3 \%$ & $88,5 \%$ \\
\hline 2 & $\begin{array}{l}\text { Mengaplikasikan konsep } \\
\text { untuk menyelesaikan masalah } \\
\text { matematika }\end{array}$ & $63,3 \%$ & $83,4 \%$ \\
\hline 3 & $\begin{array}{l}\text { Mengkonstruksi konsep } \\
\text { dengan multi-representasi } \\
\text { matematis. }\end{array}$ & $55,7 \%$ & $72,1 \%$ \\
\hline 4 & $\begin{array}{l}\text { Memliki kemampuan untuk } \\
\text { memilih prosedur penyelesain } \\
\text { yang tepat untuk masalah }\end{array}$ & $36,7 \%$ & $79,2 \%$ \\
\hline
\end{tabular}


Dari hasil Tabel 4 dan 5 terlihat bahwa indikator memberikan contoh dan bukan contoh dari suatu konsep memiliki persentase skor pada kelas eksperimen leibh tinggi dari kelas kontrol. Perbedaan persentase yang signifikan ini menunjukan bahwa siswa yang diajarkan dengan menggunakan pendekatan SAVI mampu memberikan contoh dan bukan contoh suatu konsep.

Berdasarkan Tabel 4 dan 5 terlihat bahwa indikator mengaplikasikan konsep atau algoritma dalam pemecahan masalah antara kelas eksperimen dengan kelas kontrol tidak begitu jauh perbedaannya. Akan tetapi persentase skor kelas eksperimen masih lebih tinggi dari kelas kontrol. Dengan demikian siswa yang diajarkan dengan menggunakan pendekatan SAVI mampu mengaplikasikan konsep atau algoritma dalam pemecahan masalah lebih baik.

Hasil Tabel 4 dan 5 juga memperlihatkan bahwa dalam persentase indikator menyajikan konsep dalam berbagai bentuk representasi matematis antara kelas eksperimen dan kelas kontrol tidak begitu jauh perbedaannya, namun kelas eksperimen masih lebih tinggi dari kelas kontrol.

Dari hasil Tabel 4 dan 5 terlihat bahwa dalam persentase memanfaatkan dan memilih prosedur atau operasi tertentu kedua kelas masih agak rendah karena persentase keduanya hanya mencapai kurang dari $50 \%$. Berdasarkan uraian diatas tingkat kemampuan pemahaman konsep matematis siswa ditinjau dari indikator yang digunakan kelas eksperimen lebih tinggi dari kelas kontrol. Hal ini menunjukan bahwa penggunaan pendekatan SAVI mempengaruhi dalam meningkatkan kemampuan pemahaman konsep matematis siswa, karena dengan menggunakan pendekatan SAVI dalam proses pembelajaran berlangsung siswa menggabungkan aktifitas gerak fisik, pendengaran, penglihatan dengan aktivitas intelektual sehingga siswa lebih efektif untuk memahami konsep matematis (Borchardt \& Bozer, 2017).

TABEL 5

INDIKATOR PEMAHAMAN KONSEP MATEMATIS SISWA PADA KELAS KONTROL

\begin{tabular}{|c|c|c|c|}
\hline \multirow[t]{2}{*}{ No } & \multirow{2}{*}{$\begin{array}{l}\text { Indikator Kemampuan } \\
\text { Pemahaman Konsep }\end{array}$} & \multicolumn{2}{|c|}{ Kelas Kontrol } \\
\hline & & Pre-test & Post-test \\
\hline 1 & $\begin{array}{l}\text { Memberikan contoh } \\
\text { konsep bangun ruang } \\
\text { dari lingkungan sekitar }\end{array}$ & $48,9 \%$ & $58,2 \%$ \\
\hline 2 & $\begin{array}{l}\text { Mengaplikasikan konsep } \\
\text { untuk menyelesaikan } \\
\text { masalah matematika }\end{array}$ & $53,3 \%$ & $73,7 \%$ \\
\hline 3 & $\begin{array}{l}\text { Mengkonstruksi konsep } \\
\text { dengan multi- } \\
\text { representasi matematis. }\end{array}$ & $56,5 \%$ & $69,9 \%$ \\
\hline 4 & Memliki kemampuan & $45,3 \%$ & $54,5 \%$ \\
\hline
\end{tabular}

untuk memilih prosedur penyelesain yang tepat untuk masalah

Pada pembelajaran ini untuk memenuhi keempat unsur tersebut siswa membentuk kelompok diskusi yang terdiri dari empat orang setiap kelompoknya. Pada tahap ini siswa membuat jaring-jaring bangun ruang, mengisi LKS. Secara tidak langsung pada tahap ini siswa sedang menerapkan bagian dari unsur SAVI yaitu, somatic dapat dilihat ketika siswa menggerakan bagian tubuhnya dengan membuat jaring-jaring bangun ruang, mengisi LKS dan menggambarkannya, auditory dapat dilihat ketika siswa berbicara untuk mengungkapkan gagasannya dan teman lainnya mendengarkan, visual ketika siswa dapat melihat secara langsung jaring-jaring bangun ruang yang dibuat kelompoknya masing-masing dan intellectual terlihat ketika siswa sedang menyelesaikan soal yang terdapat pada LKS tersebut.

\section{IV.KESIMPULAN}

Siswa yang belajar matematika dengan pendekatan SAVI dapat meningkatkan rata-rata skor hasil belajar siswa sebesar 22,527 dengan simpangan baku sebesar 5,6025. Tingginya rata-rata skor ini diperkuat oleh kemampuan analisis siswa dalam menyelesaikan masalah matematika melalui implementasi konstruksi konsep pada masalah yang sedang diberikan. Siswa dengan cermat memahami masalah lalu secara mandiri membentuk pemecahan masalah dengan mengimplementasikan konsep-konsep matematika yang telah dipelajarinya.

Hasil pembelajaran matematika pada kelas kontrol memiliki rata-rata skor kemampuan pemahaman konsep matematis yang mencapai 20,057 dengan nilai simpangan baku 6,154. Kemampuan siswa dalam memahami konsep matematika pada kelas kontrol membutuhkan waktu dan tenaga yang ekstra buat guru. Data hasil analisis melaporkan bahwa rata-rata skor siswa yang belajar dengan menggunakan pendekatan SAVI telah menunjukkan peningkatan yang signifikan. Penigkatan siginifikan ini tidak lepas dari cara guru mendorong siswa untuk lebih aktif dalam proses pembelajaran. Keaktifan siswa telah memotivasi siswa untuk belajar lebih bersemangat dan giat agar mendapatkan kemampuan pemahaman konsep matematika yang lebih baik.

\section{DAFTAR PUSTAKA}

Alim, E. S., Umam, K., \& Rohim, S. (2015). Integration of reciprocal teaching-ICT model to improve students' mathematics critical thinking ability. In Workshop Proceedings of the 23rd International Conference on Computers in Education, ICCE 2015.

Alim, E. S., Umam, K., \& Wijirahayu, S. (2016). The implementation of blended learning instruction by utilizing wechat application. In ICCE 2016 - 24th International Conference on Computers in 


\section{A - - Jurnal Pendidikan Matematika Indonesia \\ Volum 4 Nomor 2 bulan September 2019 Page 53 - 57 \\ p-ISSN: 2477-5967 e-ISSN: 2477-8443}

Education: Think Global Act Local - Workshop

Proceedings.

Anhalt, C. O., \& Cortez, R. (2016). Developing understanding of mathematical modeling in secondary teacher preparation. Journal of Mathematics Teacher Education, 19(6). https://doi.org/10.1007/s10857-015-9309-8

Borchardt, J., \& Bozer, A. H. (2017). Psychology course redesign: an interactive approach to learning in a micro-flipped classroom. Smart Learning Environments, 4(1), 10. https://doi.org/10.1186/s40561-017-0049-3

Canellas, M., \& Kendall, J. L. (2018). The Flipped Classroom: Addressing the Ultrasound Curriculum Gap in Undergraduate Medical Education. Medical Science Educator, 28(2), 303-307. https://doi.org/10.1007/s40670-018-0539-0

Ero-Tolliver, I., Lucas, D., \& Schauble, L. (2013). Young Children's Thinking About Decomposition: Early Modeling Entrees to Complex Ideas in Science. Research in Science Education, 43(5), 2137-2152. https://doi.org/10.1007/s11165-012-9348-4

Husita, D. (2014). Penerapan Metode Koperatif Tipe Savi (Somatic Auditory Visual And Intellectual) Animasi Komputasi Sederhana Untuk Meningkatkan Ketuntasan Belajar Kimia Pada Materi Ikatan Kimia Siswa Kelas X-6 MAN Rukoh Kota Banda Aceh. Lantanida Journal, 2(2).

Long, T., Cummins, J., \& Waugh, M. (2017). Use of the flipped classroom instructional model in higher education: instructors' perspectives. Journal of Computing in Higher Education, 29(2), 179-200. https://doi.org/10.1007/s12528-016-9119-8

Nio, T. H. (2016). Pendekatan Savi ( Somatis Auditori Visual Intelektual ) Untuk Meningkatkan Kreativitas, Kemandirian Belajar, Dan Kepercayaan Diri Dalam Pembelajaran Matematika. In Seminar Nasional Matematika X Universitas Negeri Semarang (pp. 509-522).

Rizky, I. De, Ariyanto, L., \& Sutrisno. (2017). Meningkatkan Kemampuan Berpikir Kritis Matematis Siswa kelas X dengan pembelajaran menggunakan Android Package. In Prosiding SEMINAR NASIONAL MATEMATIKA DAN PENDIDIKAN MATEMATIKA (2nd SENATIK) (pp. 139-145).

Septiany, V., Purwanto, S. E., \& Umam, K. (2015). Influence of learning on realistic mathematics ICTAssisted mathematical problem solving skills students. In Work-In-Progress Poster-Proceedings of the 23rd International Conference on Computers in Education, ICCE 2015.

Suswandari, Armiyati, L., Umam, K., Asiah, N., \& Susanti, E. N. (2017). Improving Jakarta historical understanding ability through inquiry learning model assisted with ICT among junior high school students. In ICCE 2017 - 25th International Conference on Computers in Education: Technology and Innovation: Computer-Based Educational Systems for the 21 st Century, Workshop Proceedings.

Sutarna, N. (2018). Pengaruh Model Pembelajaran SAVI (Somatic Auditory Visual Intellectualy) Terhadap Hasil Belajar Siswa Kelas IV Sekolah Dasar. Profesi Pendidikan Dasar, 5(2), 119-126.

Tague, J., \& Czocher, J. (2016). A Theoretical Approach to Ensuring Instructional and Curricular Coherence in the Flipped Classroom Model of a Differential Equations Course. International Journal of Research in Undergraduate Mathematics Education, 2(2), 223-245. https://doi.org/10.1007/s40753-0160028-Z

Umam, K. (2011). Perbedaan Hasil Belajar Matemtika Siswa dengan Metode Problem Posing dan Metode Ekspositori di SMPN 188 Jakarta Materi Teorema Pythagoras. In Prosiding Seminar nasional Matematika dan PEndidikan Matematika 2011 (pp. 182-190).

Umam, K. (2018). Peningkatan Kemampuan Berpikir Matematis Siswa melalui pembelajaran Reciprocal Teaching. Jurnal Pendidikan Matematika Indonesia, 3(2), 57-61.

Umam, K., Nusantara, T., Parta, I. N., \& Hidayanto, E. (2018). Mathematical Meaning In Modelling Context Through The Onto-Semiotics Approach. International Journal of Insight for Mathematics Teaching, 01(2), 151-159.

Umam, K., Nusantara, T., Parta, I. N., Hidayanto, E., \& Mulyono, H. (2019). An Application of Flipped Classroom in Mathematics Teacher Education Programme. International Journal of Interactive Mobile Technologies (IJIM), 13(03), 68. https://doi.org/10.3991/ijim.v13i03.10207

Umam, K., \& Supiat. (2019). Pengaruh Pembelajaran Kooperatif Tipe STAD dengan Bantuan Website terhadap Kemampuan Pemahaman Konsep Geometri Siswa Kelas VIII. Jurnal Elemen, 5(2), 170-177. https://doi.org/10.29408/jel.v5i2.1297

Umam, K., \& Yudi. (2016). Pengaruh Menggunakan Software Macromedia Flash 8 Terhadap Hasil Belajar Matematika Siswa Kelas VIII. KALAMATIKA Jurnal Pendidikan Matematika, 1(1), 84. https://doi.org/10.22236/kalamatika.vol1no1.2016p p84-92 